\title{
Evaluating the association between hybrid magnetic resonance positron emission tomography and cardiac-related outcomes in cardiac sarcoidosis
}

Maria Giovanna Trivieri MD PhD ${ }^{a, b}, *$, Philip M. Robson $\mathrm{PhD}^{\mathrm{a}, *}$, Vittoria Vergani $\mathrm{MD}^{c}$, Gina LaRocca $\mathrm{MD}^{\mathrm{b}}$, Angelica M. Romero-Daza MD ${ }^{d}$, Ronan Abgral MD PhD ${ }^{\mathrm{e}}$, Nicolas A. Karakatsanis PhD ${ }^{\mathrm{a}, \mathrm{f}}$, Aditya Parikh $M D^{b}$, Christia Panagiota $M D^{b}$, Anna Palmisano $M^{g}$, Louis DePalo $M D^{h}$, Helena L. Chang $M S^{i}$, Joseph $H$. Rothstein $\mathrm{MS}^{\mathrm{i}}$, Rima A. Fayad MPH ${ }^{\mathrm{a}}$, Marc A. Miller $\mathrm{MD}^{\mathrm{j}}$, Valentin Fuster MD PhD ${ }^{\mathrm{b}}$, Jagat Narula MD $P h D^{b}$, Marc R. Dweck MD PhD ${ }^{k}$, Adam Jacobi MD', Maria Padilla $M D^{h}$, Jason C. Kovacic MD PhD ${ }^{b, m}$, Zahi A. Fayad PhD

\footnotetext{
${ }^{a}$ BioMedical Engineering and Imaging Institute, Icahn School of Medicine at Mount Sinai, New York, NY

${ }^{b}$ Cardiovascular Institute, Icahn School of Medicine at Mount Sinai, New York, NY

'School of Biomedical Engineering and Imaging Sciences, King's College London, London, UK

dDepartment of Cardiology, Hospital La Luz - Quirón Salud, Madrid, Spain

${ }^{\mathrm{e}}$ Department of Nuclear Medicine, University Hospital of Brest, European University of Brittany, EA3878 GETBO, Brest, France

fDivision of Radiopharmaceutical Sciences, Department of Radiology, Weill Cornell Medical College, New York, NY

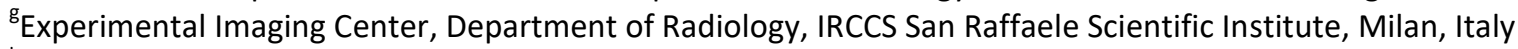

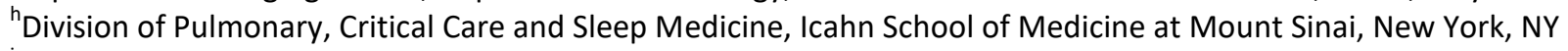

IInternational Center for Health Outcomes and Innovation Research, Department of Population Health Science and Policy, Icahn School of Medicine at Mount Sinai, New York, NY

${ }^{\mathrm{j}}$ Helmsley Electrophysiology Center, Icahn School of Medicine at Mount Sinai, New York, NY

${ }^{k}$ British Heart Foundation Centre for Cardiovascular Science, University of Edinburgh, Edinburgh, UK

'Department of Radiology, Icahn School of Medicine at Mount Sinai, New York, NY

${ }^{m}$ Victor Chang Cardiac Research Institute, Darlinghurst, Australia and; St Vincent's Clinical School, University of NSW, Australia.
}

Address for correspondence:

Maria Giovanna Trivieri, MD, PhD

One Gustave L. Levy Place, Box \#1030

New York, NY 10029-6574

Telephone: 212-241-0511

Fax: 212-241-3684

Mariagiovanna.trivieri@mountsinai.org

*Authors contributed equally

\section{Funding}

This work was supported by NIH grant R01 HL071021 (ZAF), NIH grant KL2 TR001435 (MGT) and AHA grant 20CDA35310099 (MGT). 
medRxiv preprint doi: https://doi.org/10.1101/2022.01.13.22269230; this version posted January 14, 2022. The copyright holder for this preprint (which was not certified by peer review) is the author/funder, who has granted medRxiv a license to display the preprint in perpetuity.

All rights reserved. No reuse allowed without permission.

\begin{abstract}
Objectives: To evaluate an extended hybrid MR/PET imaging strategy in cardiac sarcoidosis (CS) employing qualitative and quantitative assessment of PET tracer uptake, and to evaluate its association with cardiac-related outcomes.
\end{abstract}

Background: Invasive endomyocardial biopsy is the gold standard to diagnose CS, but it has poor sensitivity due to the patchy distribution of disease. Imaging with hybrid late gadolinium enhancement (LGE) MR and ${ }^{18} \mathrm{~F}$-fluorodexyglucose $\left({ }^{18} \mathrm{~F}\right.$-FDG) PET allows simultaneous assessment of myocardial injury and disease activity and has shown promise for improved diagnosis of active CS based on the combined positive imaging outcome, $\mathrm{MR}(+) \mathrm{PET}(+)$.

Methods: 148 patients with suspected CS were enrolled for hybrid MR/PET imaging. Patients were classified based on presence/absence of LGE (MR+/MR-), presence/absence of ${ }^{18} \mathrm{~F}-\mathrm{FDG}$ (PET+/PET-), and pattern of ${ }^{18} \mathrm{~F}$-FDG uptake (focal/diffuse) into the following categories: MR(+)PET(+) FocAL, MR(+)PET(+) DIFFUSE, MR(+)PET(-), MR(-)PET(+) FOCAL, MR(-)PET(+) DIFFUSE, MR(-)PET(-). Patients classified as $\mathrm{MR}(+) \mathrm{PET}(+)_{\text {FOCAL }}$ were designated as having active CS [aCS(+)], while all others were considered as having inactive or absent CS and designated aCS(-). Quantitative values of standard uptake value (SUVmax), target-to-background ratio (TBRmax), target-to-normal-myocardium ratio (TNMRmax) and T2 were measured. Occurrence of a cardiac-related clinical outcome was defined as any of the following during the 6-month period after imaging: cardiac arrest, ventricular arrhythmia, complete heart block, need for cardiac resynchronization/defibrillator/pacemaker/monitoring device (CRT-D, ICD/WCD, or ILR). MR/PET imaging results were compared to the presence of the composite clinical outcome.

Results: Patients designated $\mathrm{aCS}(+)$ had more than 4-fold increased odds of meeting the clinical endpoint compared to aCS(-) (unadjusted odds ratio 4.8; 95\% $\mathrm{Cl} 2.0-11.4 ; \mathrm{p}<0.001$ ). TNMRmax achieved an area under the receiver operating characteristic curve of 0.90 for separating aCS(+) from aCS(-).

Conclusions: Hybrid MR/PET imaging with an extended image-based classification of CS was statistically associated with clinical outcomes in CS. TNMRmax had high sensitivity and excellent specificity for quantifying the imaging-based classification of active CS.

Keywords: MR/PET, hybrid imaging, nuclear cardiology, cardiac sarcoidosis

\title{
Condensed Abstract
}

Imaging with hybrid late gadolinium enhancement (LGE) MR and ${ }^{18} \mathrm{~F}$-fluorodexyglucose $\left({ }^{18} \mathrm{~F}\right.$-FDG) PET allows simultaneous assessment of myocardial injury and disease activity and has shown promise for improved diagnosis of active cardiac sarcoidosis (CS). In this study, 148 patients with suspected CS were enrolled for hybrid MR/PET imaging. Patients were classified based on presence/absence of LGE (MR+/MR-), presence/absence of ${ }^{18} \mathrm{~F}-\mathrm{FDG}$ (PET+/PET-), and pattern of ${ }^{18} \mathrm{~F}-\mathrm{FDG}$ uptake (focal/diffuse). Patients classified as MR(+)PET(+) FOCAL were designated as having active CS and, compared to patients with any other imaging pattern, they had more than 4-fold increased odds of cardiac-related outcome at 6 months from imaging. 
medRxiv preprint doi: https://doi.org/10.1101/2022.01.13.22269230; this version posted January 14, 2022. The copyright holder for this preprint (which was not certified by peer review) is the author/funder, who has granted medRxiv a license to display the preprint in perpetuity.

All rights reserved. No reuse allowed without permission.

\section{List of abbreviations}

CS - Cardiac Sarcoidosis

${ }^{18} \mathrm{~F}$-FDG $-{ }^{18} \mathrm{~F}$-fluorodeoxyglucose

PET - Positron Emission Tomography

MR - Magnetic Resonance

LGE - Late Gadolinium Enhancement

SUVmax - Maximum Standard Uptake Value

TBRmax - Maximum Target-to-Background Ratio

TNMRmax - Maximum Target-to-Normal-Myocardium Ratio

aCS(+) - positive for active Cardiac Sarcoidosis

aCS(-) - negative for active Cardiac Sarcoidosis

CRT-D - cardiac resynchronization therapy device

ICD - implantable cardioverter defibrillator

S-ICD - subcutaneous implantable cardioverter defibrillator

WCD - wearable cardioverter defibrillator

ILR - implantable loop recorder

bSSFP - balanced Steady-State Free-Precession

LV - Left Ventricle

RV - Right Ventricle

AUC - Area Under the Curve

OR - Odds Ratio

$\mathrm{Cl}$-Confidence Interval 
medRxiv preprint doi: https://doi.org/10.1101/2022.01.13.22269230; this version posted January 14, 2022. The copyright holder for this preprint (which was not certified by peer review) is the author/funder, who has granted medRxiv a license to display the preprint in perpetuity.

All rights reserved. No reuse allowed without permission.

\section{Introduction}

Sarcoidosis is a rare multisystem, granulomatous disease that affects people of all ages and ethnic groups.(1) Among the several organs that can be infiltrated by sarcoid granulomas, the heart is an increasingly recognized site of disease involvement.(2) Clinically manifest cardiac sarcoidosis (CS) is present in $5-10 \%$ of patients,(3) but autopsy studies report cardiac involvement in at least $25 \%$ of cases. $(4,5)$ Of note, active CS is associated with increased mortality independently of clinical manifestations. $(2,5)$ For this reason, accurate diagnosis of subclinical disease could significantly impact on disease natural history and prognosis.

To date, diagnosis of CS is still lacking an effective gold standard. Histopathological diagnosis with endomyocardial biopsy is inherently insensitive, given the patchy distribution and intramyocardial localization of the disease.(3) A recent expert consensus statement suggested an integrated diagnostic approach using a combination of typical symptoms as well as findings on complementary cardiac imaging modalities that can identify pathological hallmarks of $\mathrm{CS}$, namely inflammation, detected by ${ }^{18} \mathrm{~F}$ fluorodeoxyglucose ( ${ }^{18} \mathrm{~F}$-FDG) positron emission tomography (PET), and scar tissue, detected by cardiac magnetic resonance (MR) with late gadolinium enhancement (LGE) contrast.(6) In addition, both modalities have been proven to have an important prognostic role. $(7,8)$

Hybrid MR/PET imaging incorporates the advantages of both imaging techniques with a single scan and allows precise co-registration of LGE MR and ${ }^{18}$ F-FDG PET images. Accordingly, it appears to hold the greatest promise for the diagnosis of active CS, providing incremental information about both the pattern of injury and disease activity in a single scan.(9-11)

In our previous work,(9) we evaluated hybrid MR/PET imaging results of CS by assigning data to one of the four imaging categories: MR(+)PET(+), MR(+)PET(-), MR(-)PET(+), MR(-)PET(-). Of these, only $\mathrm{MR}(+) \mathrm{PET}(+)$ was designated as positive for active cardiac sarcoidosis [aCS(+)]. All others were designated negative [aCS(-)]. The rationale for the joint designation was two-fold. Firstly, it is wellknown that background physiological uptake of ${ }^{18} \mathrm{~F}-\mathrm{FDG}$ in the myocardium can lead to false positive PET results; hence corroboration of disease was provided by the presence of scarring on LGE MR. Secondly, the presence of scarring on LGE MR can represent chronic or acute disease, and the concurrent finding of ${ }^{18} \mathrm{~F}$-FDG uptake indicated active disease. This approach was still limited by the theoretical possibility of active inflammation occurring prior to manifest scarring, or of failed myocardial suppression of physiological uptake in patients with chronic scarring and inactive disease.

In our previous study,(9) we established that maximum target-to-normal-myocardium ratio (TNMRmax), a novel quantitative PET parameter to measure the ratio of PET tracer uptake at diseased and normal regions of the myocardium based on the presence of scarring on LGE MR, separated patients categorized as aCS(+) or aCS(-) by hybrid imaging. In addition, we noted that failed myocardial suppression often presented with intense and diffuse appearance of ${ }^{18} \mathrm{~F}$-FDG uptake, as has been observed by others previously. $(6,12)$

In this study, we sought to confirm the role of hybrid MR/PET in a larger sample (148 patients) with known or suspected CS, using an extended imaging strategy to differentiate active from inactive myocardial disease and better identify false-positive ${ }^{18}$ F-FDG uptake. Importantly, we also sought to evaluate the potential prognostic capability of this imaging assessment by determining whether a 
medRxiv preprint doi: https://doi.org/10.1101/2022.01.13.22269230; this version posted January 14, 2022. The copyright holder for this preprint (which was not certified by peer review) is the author/funder, who has granted medRxiv a license to display the preprint in perpetuity.

All rights reserved. No reuse allowed without permission.

designation of $\mathrm{aCS}(+)$ by imaging conferred a greater likelihood of a cardiac-related clinical outcome during follow-up of the same cohort.

\section{Methods}

Study population

148 patients with clinical suspicion of active CS due to established extra-cardiac involvement and/or clinical presentation suggestive of the disease were recruited at Mount Sinai Hospital, New York. This study was approved by our Institutional Review Board of the Icahn School of Medicine at Mount Sinai (GCO 01-1032) and all patients gave written informed consent. Exclusion criteria included: insulindependent diabetes mellitus, blood sugar $>200 \mathrm{mg} / \mathrm{dL}$ prior to scanning, claustrophobia, pregnancy/nursing, presence of an implanted device contraindicated for MRI prior to the study, and impaired renal function (estimated glomerular filtration rate $<40 \mathrm{ml} / \mathrm{min} / 1.73 \mathrm{~m}^{2}$ ).

Additional clinical information was collected where available, including but not limited to: current treatment with corticosteroids and/or immunosuppresants; symptoms, including syncope, palpitations, dyspnea, and clinical heart failure; blood markers of inflammation and heart failure; and electrophysiological history, namely atrioventricular block, fascicular block, and bundle branch block.

\section{Patient follow-up}

Patients were followed-up by chart review up to 6 months after their scan date to determine progression to a composite clinical endpoint including: cardiac-related death, aborted cardiac arrest, sustained ventricular arrhythmia, complete heart block, cardiac device requirement (pacemaker, cardiac resynchronization therapy device (CRT-D), implantable cardioverter defibrillator (ICD) or wearable cardioverter defibrillator (WCD), implantable loop recorder (ILR)). The decision to implant a cardiac device was made based on best clinical judgement and a combination of factors including clinical and imaging history and/or other indications such as inducible sustained ventricular arrhythmia at electrophysiological testing.

\section{Scanning protocol}

Each patient underwent simultaneous cardiac MR with LGE and ${ }^{18}$ F-FDG PET cardiac imaging on a hybrid MR/PET system (Biograph-mMR, Siemens Healthineers).

PET imaging. PET imaging was performed as previously described.(9) Patients were required to fast for at least 4 hours, and to follow a low-carbohydrate high-fat diet for 24 hours prior to the study in concordance with published guidelines.(12) Patients were then injected intravenously with approximately $5 \mathrm{MBq} / \mathrm{kg}$ of ${ }^{18} \mathrm{~F}-\mathrm{FDG}$. PET data were subsequently acquired, in a single bed position centered on the heart, between 40-100 minutes post injection and reconstructed into a single static PET frame for both visual and quantitative PET analyses. PET image reconstruction employed an iterative ordinary Poisson ordered-subsets expectation-maximization algorithm with 21 subsets and 3 iterations incorporating point-spread-function resolution modeling, a $344 \times 344 \times 127$ matrix and a 2-mm full-width- 
medRxiv preprint doi: https://doi.org/10.1101/2022.01.13.22269230; this version posted January 14, 2022. The copyright holder for this preprint (which was not certified by peer review) is the author/funder, who has granted medRxiv a license to display the preprint in perpetuity.

All rights reserved. No reuse allowed without permission.

at-half-maximum Gaussian post-reconstruction filter. Attenuation correction for the body in the PET reconstruction was estimated using MR imaging. A recently proposed free breathing 3D radial gradientecho acquisition was used to compensate for respiratory motion in the attenuation map.(13)

Cardiac MR sequences. Cardiac MR was performed simultaneously and included balanced steady-state free-precession (bSSFP) cine images (2-chamber, 4-chamber, and complete short axis stack) and T2prepared bSSFP T2 mapping acquired in the basal, mid-ventricular and apical short-axis planes with three T2 preparation times $(0,25,50 \mathrm{~ms})$. Electrocardiograph-triggered, inversion-recovery fast gradient-echo LGE sequences were acquired 10 to 15 minutes after injection of $0.2 \mathrm{mmol} / \mathrm{kg}$ gadolinium contrast agent (Multihance, Bracco Imaging, Milan, Italy). Inversion times were optimized to null normal myocardium.

\section{Cardiac MR analysis}

Left ventricular (LV) mass, biventricular volumes and ejection fractions were quantified from cine images by manually tracing the endocardial and epicardial contours on the short axis views in end-diastole and end-systole(14) using dedicated software (cvi42, Circle Cardiovascular Imaging, Calgary, Canada).

Late gadolinium enhancement. The presence and pattern of LV and right ventricular (RV) myocardial LGE (subendocardial, midwall, subepicardial, transmural) and whether this was characteristic of cardiac sarcoidosis were determined by 3 experienced operators (MGT, GL, AMRD). LGE was also quantified as a percentage of the total myocardial mass with dedicated software (cvi42, Circle Cardiovascular Imaging, Calgary, Canada).

T2. Basal, mid-ventricular and apical T2 maps were generated with dedicated software (cvi42, Circle Cardiovascular Imaging, Calgary, Canada), by two expert operators (VV, AMRD). A T2 value was extracted for each myocardial AHA segment, following the standard 16-segment AHA LV segmentation(15). The T2 value of the segment(s) including LGE was then selected. If no LGE was present, the average mid-ventricular $\mathrm{T} 2$ was used.

\section{PET analysis}

Qualitative. Each scan was assessed systematically for extracardiac disease in the thoracic field. Analysis of myocardial ${ }^{18} \mathrm{~F}$-FDG uptake on fused MR/PET datasets was performed using OsiriX-Lite software (OsiriX-imaging, Geneva, Switzerland). First, small adjustments were made to achieve accurate coregistration in 3 dimensions between the LGE MR and PET scans using anatomical markers.

Quantitative. PET quantification was performed on fused short axis LGE MR and ${ }^{18}$ F-FDG PET datasets by an experienced nuclear medicine physician (RA). Three different measures were recorded, as explained in our previous work:(9) maximum standard uptake values (SUVmax); maximum tissue-to-background ratio (TBRmax), where myocardial SUVmax was corrected for blood pool mean activity measured in the right ventricle; maximum target-to-normal-myocardium ratio (TNMRmax), where myocardial SUVmax was corrected for tissue mean activity measured in a contralateral myocardial segment without LGE. Maximum values were used in preference to mean values due to the difficulties in drawing consistent regions of interest. 
medRxiv preprint doi: https://doi.org/10.1101/2022.01.13.22269230; this version posted January 14, 2022. The copyright holder for this preprint (which was not certified by peer review) is the author/funder, who has granted medRxiv a license to display the preprint in perpetuity.

All rights reserved. No reuse allowed without permission.

\section{Hybrid MR/PET image analysis}

Qualitative analysis to assign category. Co-registered short axis hybrid LGE MR and ${ }^{18}$ F-FDG PET images were then assessed and patients categorized into the following four groups: $M R(+) \operatorname{PET}(+)$, MR(+)PET(-), MR(-)PET(+), MR(-)PET(-), similarly to our previous study.(9) The PET(+) groups were further subdivided according to the characteristic appearance of the ${ }^{18} \mathrm{~F}-\mathrm{FDG}$ PET signal, resulting in the following six image-based categories (Figure 1):

1) $\mathrm{MR}(+) \mathrm{PET}(+)_{\text {FOCAL }}$ when a characteristic pattern of LGE and a pattern of increased focal ${ }^{18} \mathrm{~F}-\mathrm{FDG}$ uptake were both present - assigned as positive active CS [aCS(+)].

2) $\mathrm{MR}(+) \mathrm{PET}(+)_{\text {DIFFUSE }}$ when a characteristic pattern of LGE was present and diffuse ${ }^{18} \mathrm{~F}$-FDG uptake was present, suggestive of failed suppression of physiological uptake - assigned as negative active CS [aCS(-)].

3) $\mathrm{MR}(+) \mathrm{PET}(-)$, defined by characteristic LGE but no increased ${ }^{18} \mathrm{~F}-\mathrm{FDG}$ - representative of inactive cardiac sarcoidosis with residual scar, and assigned aCS(-).

4) $\mathrm{MR}(-) \mathrm{PET}(+)_{\text {Focal }}$ if there was increased patchy, focal ${ }^{18} \mathrm{~F}$-FDG uptake in the absence of underlying LGE - assigned aCS(-).

5) MR(-)PET(+) $)_{\text {DIFFUSE }}$ if there was increased diffuse ${ }^{18}$ F-FDG uptake in the absence of underlying LGE - assigned aCS(-).

6) MR(-)PET(-) if there was neither characteristic LGE nor increased ${ }^{18}$ F-FDG - assigned aCS(-).

Figure 1: Combined PET/MR patterns.

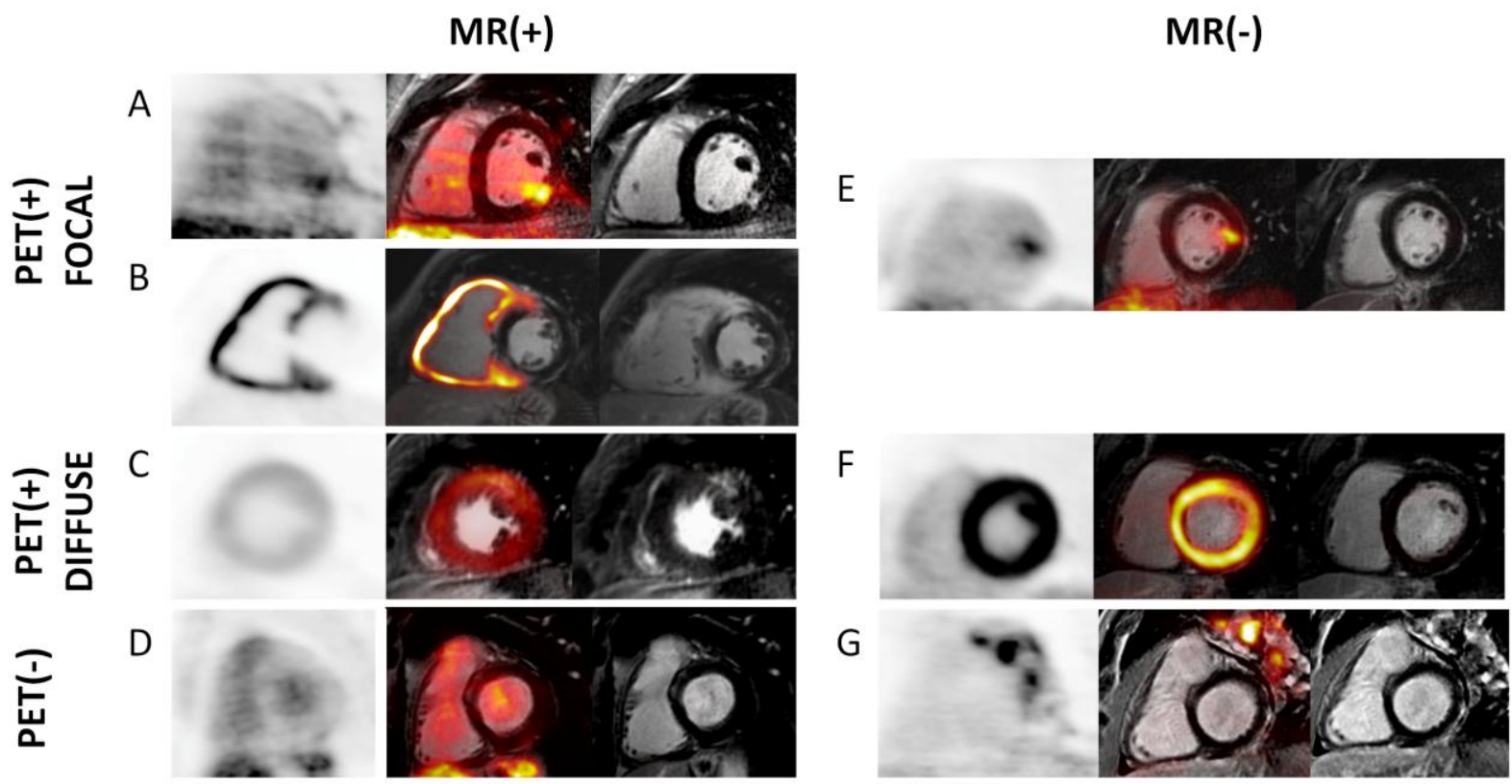

Representative short axis ${ }^{18}$ F-FDG PET (left), LGE MR (right) and fused MR/PET (middle) images for each of the six image-based categories. A: $M R(+) P E T(+)_{F O C A L}, B: M R(+) P E T(+)_{F O C A L}$ with predominantly right ventricular involvement that was subsequently confirmed by cardiac biopsy, C: MR(+)PET(+) DIFFUSE , D: MR(+)PET(-), E: MR(-)PET(+) FOCAL F: MR(-)PET(+) DIFFUSE , G: MR(-)PET(-) with extra-cardiac ${ }^{18}$ F-FDG uptake. 
medRxiv preprint doi: https://doi.org/10.1101/2022.01.13.22269230; this version posted January 14, 2022. The copyright holder for this preprint (which was not certified by peer review) is the author/funder, who has granted medRxiv a license to display the preprint in perpetuity.

All rights reserved. No reuse allowed without permission.

\section{Statistical Analysis}

Descriptive statistics were used to characterize the cohort. Continuous variables were described as mean \pm standard deviation when normally distributed, otherwise median and inter-quartile range. Categorical variables were presented as $\mathrm{n}(\%)$. Quantitative PET and MR values were compared pairwise between each of the 6 image-based categories, and between selected groupings of the categories, using a two-sample two-sided t-test. Receiver operating characteristic curve analysis was performed and area under the curve reported to evaluate the ability of quantitative PET parameters (SUVmax, TBRmax, TNMRmax) and T2 to separate aCS(+) from aCS(-). The Youden index was used to determine the optimal threshold that differentiated $\mathrm{aCS}(+)$ from aCS(-) patients and sensitivity and specificity measures were calculated based on the optimal threshold. The association between the occurrence of a cardiac-related clinical outcome and the dichotomous classification of patients based on various groupings of the image-based categories was analyzed by calculating odds ratios. All hypothesis testing was conducted at the 0.05 two-sided significance level using R V3.5.3.

\section{Results}

The study cohort that underwent MR/PET imaging included 148 patients. The characteristics of the cohort are summarized in Table 1. T2 measurements were not obtained in all patients due to frequent image artifacts arising from the use of bSSFP for T2 mapping (Table 1). Examples of the 6 imaging categories used are shown in Figure 1. One patient (Figure 1, B) presented with ventricular tachycardia, in the absence of extracardiac manifestation of sarcoidosis. The patient was classified as $\mathrm{MR}(+) \mathrm{PET}(+)_{\text {FOCAL }}$ due to LGE throughout the right ventricular wall and the right ventricular insertion points suggestive of $C S$, that coincided with widespread patchy/focal ${ }^{18} \mathrm{~F}$-FDG uptake. The diagnosis of aCS(+) was subsequently confirmed by endomyocardial biopsy and the patient met the clinical endpoint, receiving an ICD.

Analysis of the quantitative PET parameters, by pair-wise comparison between each image-based category, indicated that TNMRmax was significantly higher in the aCS $(+)$ group $\left[\mathrm{MR}(+) \mathrm{PET}(+)_{\text {Focal }}\right]$ than all others (Figure 2 and Table 2). SUVmax and TBRmax were significantly higher for aCS(+) than any PET(-) category and lower than the remaining PET(+) categories. Similarly, T2 values for aCS(+) were significantly higher than any $\mathrm{MR}(-)$ category but not significantly different from the other $M R(+)$ categories, suggesting T2 values are affected by both the edematous component of inflammation(16) and myocardial scarring. Receiver operating characteristic curve analysis indicated that TNMRmax was an excellent predictor of the image-based designation of aCS(+), with an area under the curve (AUC) of 0.90 (Figure 3). The sensitivity and specificity were $88 \%$ and $95 \%$ at the Youden index point with a TNMRmax threshold for separating aCS(+) from aCS(-) of 1.4. For quantitative T2 measurements, the values of $\mathrm{AUC} / \mathrm{sensitivity/specificity} \mathrm{were} 0.72 / 79 \% / 58 \%$ with a threshold of $37 \mathrm{~ms}$. SUVmax and TBRmax were poor determinants of aCS(+), with AUCs of 0.54 and 0.57 (Table 3). 
medRxiv preprint doi: https://doi.org/10.1101/2022.01.13.22269230; this version posted January 14, 2022. The copyright holder for this preprint (which was not certified by peer review) is the author/funder, who has granted medRxiv a license to display the preprint in perpetuity.

All rights reserved. No reuse allowed without permission.

Table 1: Clinical attributes of the cohort for each MR/PET imaging designation.

\begin{tabular}{|c|c|c|c|c|c|c|c|c|c|c|}
\hline & & $\begin{array}{c}\text { Total } \\
\text { population }\end{array}$ & $\begin{array}{c}\text { MR(+)PET(+) } \\
\text { FOCAL } \\
{[\text { aCS }(+)]}\end{array}$ & $\begin{array}{c}\text { MR(+)PET(+) } \\
\text { DIFFusE }\end{array}$ & MR(+)PET(-) & $\begin{array}{c}\text { MR(-) } \\
\operatorname{PET}(+)_{\text {focAL }}\end{array}$ & $\begin{array}{c}\text { MR(-) } \\
\text { PET(+) }(+)_{\text {DIFUUSE }}\end{array}$ & MR(-)PET(-) & [acs(-)] & $\begin{array}{c}\mathbf{P} \\
\text { [acs(+) vs. } \\
\operatorname{aCS}(-)]\end{array}$ \\
\hline \multicolumn{2}{|l|}{ Number } & 148 & 34 & 14 & 23 & 18 & 21 & 38 & 114 & - \\
\hline \multicolumn{2}{|l|}{$\begin{array}{l}\text { Age, mean } \\
\text { (SD) }\end{array}$} & $56.5(9.0)$ & $57.4(10.7)$ & $55.1(7.8)$ & $58.1(8.8)$ & $59.1(7.9)$ & $53.2(9.3)$ & $55.3(7.9)$ & $56.2(8.4)$ & 0.56 \\
\hline \multicolumn{2}{|l|}{$\begin{array}{l}\text { Sex (male), n } \\
(\%)\end{array}$} & $89(59.8)$ & $24(70.6)$ & $9(64.3)$ & $15(65.2)$ & $9(50.0)$ & $13(61.9)$ & $19(50.0)$ & $65(57.0)$ & 0.16 \\
\hline \multirow[t]{5}{*}{$\begin{array}{l}\text { Medication, } \\
\mathrm{n}(\%)\end{array}$} & $\begin{array}{l}\text { ACE- } \\
\text { inhibitors }\end{array}$ & $27(18.2)$ & $7(20.6)$ & $3(1.4)$ & $3(13.0)$ & $3(16.7)$ & $3(14.3)$ & $8(21.1)$ & $20(17.5)$ & 0.69 \\
\hline & ARBS & $24(16.2)$ & $6(17.6)$ & $1(7.1)$ & $7(30.4)$ & $4(22.2)$ & $2(9.5)$ & $4(10.5)$ & $18(15.8)$ & 0.80 \\
\hline & Beta-blockers & $48(32.4)$ & $16(47.1)$ & $5(35.7)$ & $7(30.4)$ & $4(22.2)$ & $5(23.8)$ & $11(28.9)$ & $22(19.3)$ & 0.001 \\
\hline & $\begin{array}{l}\text { Corticosteroi } \\
\text { ds }\end{array}$ & $44(29.7)$ & $11(32.4)$ & $7(50.0)$ & $3(13.0)$ & $4(22.2)$ & $6(28.6)$ & $13(34.2)$ & $33(28.9)$ & 0.70 \\
\hline & $\begin{array}{l}\text { Immunosupp } \\
\text { ressants }\end{array}$ & $17(11.5)$ & $4(11.8)$ & $1(7.1)$ & $1(4.3)$ & $0(0)$ & $4(19.0)$ & $7(18.4)$ & $13(11.4)$ & 0.95 \\
\hline \multicolumn{2}{|c|}{ Extra cardiac sarcoidosis, $n(\%)$} & $85(57.4)$ & $15(44.1)$ & $11(78.6)$ & $11(73.3)$ & $12(66.7)$ & $13(61.9)$ & $24(63.2)$ & $71(62.3)$ & 0.06 \\
\hline \multirow[t]{4}{*}{$\begin{array}{l}\text { Symptoms, } \mathrm{n} \\
\text { (\%) }\end{array}$} & Syncope & $5(3.4)$ & $3(8.8)$ & $1(7.1)$ & $0(0)$ & $0(0)$ & $1(4.8)$ & $0(0)$ & $2(1.8)$ & 0.05 \\
\hline & Palpitations & $20(13.5)$ & $4(11.8)$ & $2(14.3)$ & $4(17.4)$ & $3(16.7)$ & $2(9.5)$ & $5(13.2)$ & $16(14.0)$ & 0.73 \\
\hline & Dyspnea & $57(38.5)$ & $11(32.4)$ & $4(28.6)$ & $8(34.8)$ & $7(38.9)$ & $11(52.4)$ & $16(42.2)$ & $46(40.4)$ & 0.40 \\
\hline & $\begin{array}{l}\text { Clinical heart } \\
\text { failure }\end{array}$ & $8(5.4)$ & $2(5.9)$ & $1(7.1)$ & $0(0)$ & $0(0)$ & $2(9.5)$ & $3(7.9)$ & $6(5.3)$ & 0.89 \\
\hline \multirow{3}{*}{$\begin{array}{l}\text { Blood } \\
\text { markers, } \\
\text { median (Q1- } \\
\text { Q3) }\end{array}$} & $B N P, p g / m l$ & $\begin{array}{c}41.9(24.9- \\
141.5)\end{array}$ & $\begin{array}{c}65.0(26.9- \\
210.7)\end{array}$ & $\begin{array}{l}95.1(31.4- \\
296.8)\end{array}$ & $\begin{array}{c}29.0(22.2- \\
48.0)\end{array}$ & $\begin{array}{c}31.0(26.0- \\
45.0)\end{array}$ & $\begin{array}{c}59.0(28.2- \\
119.7)\end{array}$ & $\begin{array}{c}47.5(23.5- \\
138)\end{array}$ & $\begin{array}{c}40.0(23.1- \\
107.0)\end{array}$ & 0.27 \\
\hline & $\mathrm{CRP}, \mathrm{mg} / \mathrm{L}$ & $\begin{array}{l}2.55(1.33- \\
5.35)\end{array}$ & $\begin{array}{c}1.89(1.25- \\
2.68)\end{array}$ & - & $0.8(0.6-3.8)$ & $2.6(2.2-2.8)$ & $5.8(2.4-7.2)$ & $3.8(1.6-5.7)$ & $2.9(1.4-5.7)$ & 0.08 \\
\hline & $\mathrm{WBC} / \mathrm{mm} 3$ & $6.9(5.7-8.6)$ & $6.9(4.9-8.7)$ & $6.8(6.0-8.6)$ & $6.9(6.1-7.6)$ & $7.8(6.3-9.2)$ & $6.3(5.3-7.4)$ & $7.2(6.0-9.0)$ & $7.0(5.9-8.6)$ & 0.41 \\
\hline \multirow{4}{*}{$\begin{array}{l}\text { ECG } \\
\text { abnormalities } \\
\text {, } \mathrm{n}(\%)\end{array}$} & VT & $5(3.4)$ & $0(0)$ & $0(0)$ & $2(8.6)$ & $1(5.6)$ & $1(4.8)$ & $1(2.6)$ & $5(4.4)$ & 0.21 \\
\hline & $\begin{array}{l}\text { Atrio- } \\
\text { ventricular } \\
\text { block }\end{array}$ & $11(7.4)$ & $5(14.7)$ & $1(7.1)$ & $1(4.3)$ & $0(0)$ & $1(4.8)$ & $3(7.9)$ & $6(5.3)$ & 0.07 \\
\hline & $\begin{array}{l}\text { fascicular } \\
\text { block }\end{array}$ & $18(12.2)$ & $6(16.6)$ & $2(14.3)$ & $1(4.3)$ & $2(11.1)$ & $2(9.5)$ & $5(13.2)$ & $12(10.5)$ & 0.26 \\
\hline & BBB & $25(16.9)$ & $8(23.5)$ & $3(21.4)$ & $3(13.0)$ & $2(11.1)$ & $4(19.0)$ & $5(13.2)$ & $17(14.9)$ & 0.24 \\
\hline \multirow[t]{3}{*}{$\begin{array}{l}\text { PET } \\
\text { quantification } \\
\text {, median (Q1- } \\
\text { Q3) }\end{array}$} & SUVmax & $\begin{array}{c}2.44(1.45- \\
5.82)\end{array}$ & $\begin{array}{c}2.86(2.18- \\
4.08)\end{array}$ & $\begin{array}{c}7.48(5.92- \\
10.08)\end{array}$ & $\begin{array}{c}1.39(1.22- \\
1.68)\end{array}$ & $\begin{array}{c}4.53(3.10- \\
7.31)\end{array}$ & $\begin{array}{c}6.87(5.88- \\
11.01)\end{array}$ & $\begin{array}{c}1.43(1.21- \\
1.84)\end{array}$ & $\begin{array}{c}2.24(1.38- \\
6.36)\end{array}$ & 0.08 \\
\hline & TBRmax & $\begin{array}{c}1.74(1.04- \\
3.73)\end{array}$ & $\begin{array}{c}2.03(1.65- \\
2.79)\end{array}$ & $\begin{array}{c}4.73(3.55- \\
6.46)\end{array}$ & $\begin{array}{c}0.97(0.89- \\
1.04)\end{array}$ & $\begin{array}{c}2.09(2.12- \\
4.68)\end{array}$ & $\begin{array}{c}6.58(4.71- \\
8.57)\end{array}$ & $\begin{array}{c}1.05(0.92- \\
1.19)\end{array}$ & $\begin{array}{c}1.47(1.00- \\
4.67)\end{array}$ & 0.03 \\
\hline & TNMRmax & $\begin{array}{c}1.18(1.08- \\
136) \\
\end{array}$ & $\begin{array}{c}2.09(1.51- \\
2.39) \\
\end{array}$ & $\begin{array}{c}1.11(1.06- \\
1.29) \\
\end{array}$ & $\begin{array}{c}1.12(1.08- \\
1.18) \\
\end{array}$ & $\begin{array}{c}1.19(1.13- \\
1.28) \\
\end{array}$ & $\begin{array}{c}1.15(1.04- \\
1.25) \\
\end{array}$ & $\begin{array}{c}1.14(1.06- \\
1.2) \\
\end{array}$ & $\begin{array}{c}1.14(1.07- \\
1.23) \\
\end{array}$ & 0.0001 \\
\hline \multirow[t]{3}{*}{$\begin{array}{l}\text { MR } \\
\text { quantification } \\
\text {, median (Q1- } \\
\text { Q3) }\end{array}$} & $\begin{array}{l}\text { LGE, \% of } \\
\text { total } \\
\text { myocardium }\end{array}$ & $0(0-2.87)$ & $\begin{array}{c}3.18(2.03- \\
8.78)\end{array}$ & $\begin{array}{c}2.63(0.32- \\
3.65)\end{array}$ & $\begin{array}{c}2.12(0.66- \\
3.71)\end{array}$ & $0(0)$ & $0(0)$ & $0(0)$ & $0(0-1.75)$ & 0.01 \\
\hline & $\mathrm{T} 2, \mathrm{~ms}$ & $\begin{array}{c}37.6(34.1- \\
41.5)\end{array}$ & $\begin{array}{c}41.1(37.7- \\
43.6)\end{array}$ & $\begin{array}{c}37.7(35.9- \\
42.2)\end{array}$ & $\begin{array}{c}39.5(36.3- \\
41.2)\end{array}$ & $\begin{array}{c}35.2(33.8- \\
38.0)\end{array}$ & $\begin{array}{c}34.8(33.8- \\
37.6)\end{array}$ & $\begin{array}{c}36.2(33.5- \\
38.3)\end{array}$ & $\begin{array}{c}36.8(34.0- \\
39.4)\end{array}$ & 0.01 \\
\hline & $\begin{array}{l}\mathrm{N} \text { (T2 } \\
\text { mapping) }\end{array}$ & 95 & 24 & 8 & 15 & 13 & 11 & 24 & 71 & - \\
\hline \multirow{4}{*}{$\begin{array}{l}\text { Cine cardiac } \\
\text { MR analysis, } \\
\text { median (Q1- } \\
\text { Q3) }\end{array}$} & LVEDV, $\mathrm{ml}$ & $\begin{array}{c}155(133- \\
196)\end{array}$ & $\begin{array}{l}195(143- \\
220)\end{array}$ & $\begin{array}{c}146(129- \\
158)\end{array}$ & $\begin{array}{c}171(137- \\
201)\end{array}$ & $\begin{array}{c}122(111- \\
143)\end{array}$ & $\begin{array}{c}162(154- \\
178)\end{array}$ & $\begin{array}{c}150(134- \\
182)\end{array}$ & $\begin{array}{l}150(123- \\
177)\end{array}$ & 0.05 \\
\hline & LVEF, \% & $59(51-66)$ & $55(46-62)$ & $55(49-61)$ & $61(53-67)$ & $63(56-68)$ & $56(52-65)$ & $60(54-66)$ & $60(51-66)$ & 0.07 \\
\hline & LVM, g & $93(76-112)$ & $108(81-133)$ & $101(89-112)$ & $99(77-109)$ & $78(61-98)$ & $92(81-103)$ & $90(72-101)$ & $92(74-107)$ & 0.09 \\
\hline & RVEF, \% & $56(50-91)$ & $53(46-60)$ & $53(50-56)$ & $57(50-61)$ & $58(55-66)$ & $58(56-63)$ & $56(51-63)$ & $56(50-61)$ & 0.14 \\
\hline \multicolumn{2}{|c|}{ Met clinical endpoint, $n$ (\%) } & $31(20.9)$ & $15(44.1)$ & $1(7.1)$ & $5(21.7)$ & $1(5.6)$ & $4(19.0)$ & $5(13.2)$ & $16(14.0)$ & 0.00016 \\
\hline
\end{tabular}


medRxiv preprint doi: https://doi.org/10.1101/2022.01.13.22269230; this version posted January 14, 2022. The copyright holder for this preprint (which was not certified by peer review) is the author/funder, who has granted medRxiv a license to display the preprint in perpetuity.

All rights reserved. No reuse allowed without permission.

$M R(+) P E T(+)_{F O C A L}$ is also defined as positive active cardiac sarcoid [aCS $\left.(+)\right]$, while all others are grouped into negative active CS [aCS(-)]. P-values for either a two sample $t$-tests for continuous data, or a chi-squared test for proportions are shown for the comparison of $a C S(+)$ and aCS(-). $A C E=$ angiotensin converting enzyme; $A R B=$ angiotensin receptor blocker; $B N P=B$-type natriuretic peptide; $C R P=C$-reactive protein; $W B C=$ white blood cell; $V T$ $=$ ventricular tachycardia; $B B B=$ bundle branch block; SUVmax = maximum standard uptake value; TBRmax = maximum target to background ratio; TNMRmax = maximum target to normal myocardium ratio; $L G E=$ late gadolinium enhancement; $T 2=M R$ parameter T2; LVEDV = left ventricular end-diastolic volume; $L V E F=$ left ventricular ejection fraction; $L V M=$ left ventricular mass; $R V E F=$ right ventricular ejection fraction.

Thirty one (21\%) of the 148 patients reached the composite clinical endpoint (Table 4). Of those, all had a cardiac device implanted. The proportions of patients in the aCS(+) and aCS(-) groups that reached the clinical endpoint, as well as other groupings of the 6 imaging categories, are given in Table 5. The unadjusted odds ratios (OR) and confidence intervals $(\mathrm{Cl})$ resulting from those groupings are given in Table 6, showing that patients with an imaging designation of aCS(+) had 4.8 times higher odds of reaching the clinical outcome compared to aCS(-) patients (OR 4.8; 95\% $\mathrm{Cl} 2.0-11.4 ; \mathrm{p}<0.001)$. When the analysis was conducted without accounting for the pattern of ${ }^{18} \mathrm{~F}$-FDG uptake, MR(+)PET(+) cases [combining $\mathrm{MR}(+) \mathrm{PET}(+)_{\text {FOCAL }}$ and $\mathrm{MR}(+) \mathrm{PET}(+)_{\text {DIFFUSE }}$ ] vs. all others combined, showed a similarly significant association with clinical outcomes (OR 2.8; 95\% $\mathrm{Cl} 1.3-6.4 ; \mathrm{p}=0.012)$ as $\mathrm{MR}(+)$ vs. MR(-) (OR 2.8; 95\% Cl 1.2-6.5; $\mathrm{p}=0.015)$. PET(+) alone $\left[\mathrm{PET}(+)_{\mathrm{FOCAL}}\right.$ and PET $(+)_{\text {DIFFUSE }}$ combined vs. PET(-)] showed a trend towards being associated with the clinical outcome, which did not reach statistical significance (OR 1.6; $95 \% \mathrm{Cl} 0.7-3.7 ; \mathrm{p}=0.26)$.

Figure 2: Quantitative evaluation of PET and T2 parameters for each image-based category.
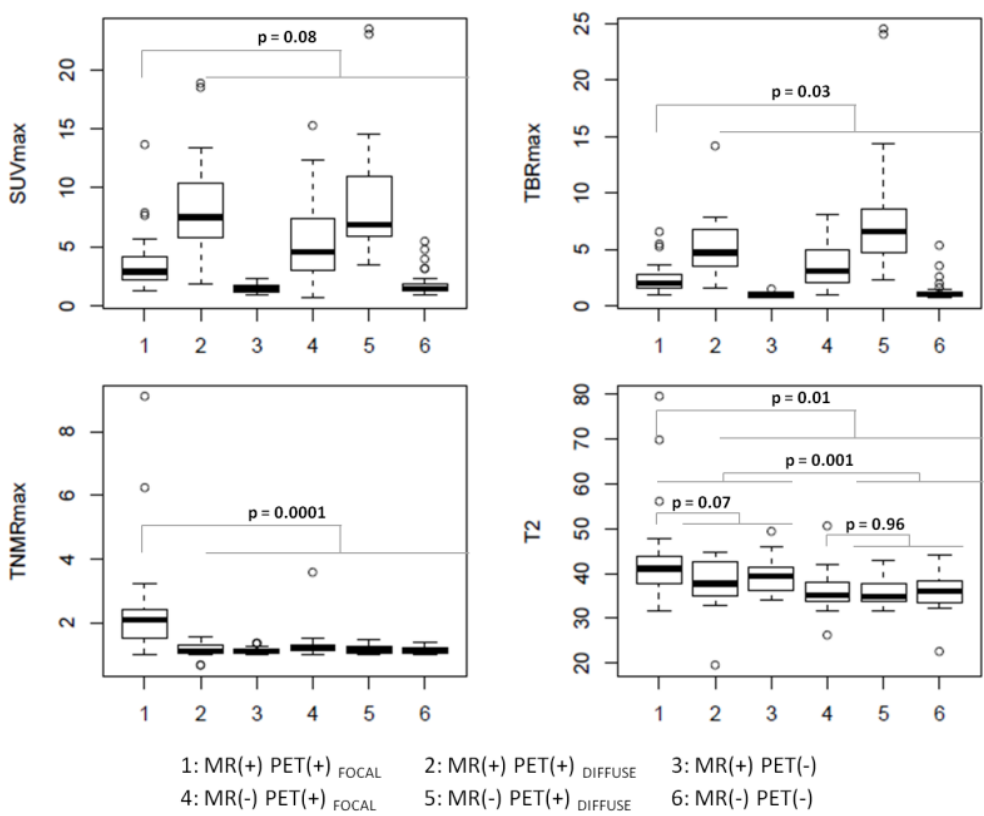

Box-and-whisker plots for the quantitative PET and T2 parameters for each image-based category. $P$-values are from two-sided two-sample t-tests between selected groupings of image-based categories. 
medRxiv preprint doi: https://doi.org/10.1101/2022.01.13.22269230; this version posted January 14, 2022. The copyright holder for this preprint (which was not certified by peer review) is the author/funder, who has granted medRxiv a license to display the preprint in perpetuity. All rights reserved. No reuse allowed without permission.

Table 2: Group-by-group comparison of two-sample two-sided t-tests for quantitative PET and MR parameters.

\begin{tabular}{|c|c|c|c|c|c|c|c|c|c|c|c|c|c|c|c|c|c|c|c|c|}
\hline & \multicolumn{4}{|c|}{$\begin{array}{c}\text { MR(+) } \\
\operatorname{PET}(+)_{\text {DIFFUSE }}\end{array}$} & \multicolumn{4}{|c|}{$\begin{array}{l}\text { MR(+) } \\
\operatorname{PET}(-)\end{array}$} & \multicolumn{4}{|c|}{$\begin{array}{c}\text { MR(-) } \\
\text { PET(+) })_{\text {FOCAL }}\end{array}$} & \multicolumn{4}{|c|}{$\begin{array}{c}\text { MR(-) } \\
\text { PET(+) })_{\text {DIFFUSE }}\end{array}$} & \multicolumn{4}{|c|}{$\begin{array}{l}\text { MR(-) } \\
\text { PET(-) }\end{array}$} \\
\hline & そ & 鲇 & $\sum_{i}^{\infty}$ & $\mathfrak{F}$ & 方 & 䍃 & $\sum_{\sum}^{\infty}$ & $\mathfrak{F}$ & 离 & 㤐 & $\sum_{i}^{\infty}$ & $\mathfrak{F}$ & 引 & 営 & $\sum_{i}^{\infty}$ & $\mathfrak{F}$ & 方 & 営 & $\sum_{i}^{\infty}$ & $\mathfrak{F}$ \\
\hline $\begin{array}{c}\text { MR(+) } \\
\text { PET(+) })_{\text {FOCAL }}\end{array}$ & $* *$ & $* *$ & $* *$ & ns & $* *$ & $* *$ & $* *$ & ns & * & $*$ & $* *$ & $*$ & $* *$ & $* *$ & $* *$ & $* *$ & $* *$ & $* *$ & $* *$ & $* *$ \\
\hline $\begin{array}{c}\text { MR(+) } \\
\text { PET(+) })_{\text {DIFFUSE }}\end{array}$ & & & & & $* *$ & $* *$ & ns & ns & ns & ns & ns & ns & ns & ns & ns & ns & $* *$ & $* *$ & ns & $\mathrm{ns}$ \\
\hline $\begin{array}{l}\text { MR(+) } \\
\text { PET(-) }\end{array}$ & & & & & & & & & $* *$ & $* *$ & ns & ns & $* *$ & $* *$ & ns & $*$ & ns & $*$ & $\mathrm{~ns}$ & $*$ \\
\hline $\begin{array}{c}\text { MR(-) } \\
\text { PET(+) })_{\text {FOCAL }}\end{array}$ & & & & & & & & & & & & & $*$ & $* *$ & $\mathrm{~ns}$ & $\mathrm{~ns}$ & $* *$ & $* *$ & $\mathrm{~ns}$ & $\mathrm{~ns}$ \\
\hline $\begin{array}{c}\text { MR(-) } \\
\text { PET }(+)_{\text {DIFFUSE }}\end{array}$ & & & & & & & & & & & & & & & & & $* *$ & $* *$ & ns & ns \\
\hline
\end{tabular}

SUVmax = maximum standard uptake value, TBRmax = maximum target to background ratio, TNMRmax $=$ maximum target to normal myocardium ratio, and $T 2=M R$ parameter $T 2$. ${ }^{* *}=p<0.01,{ }^{*}=p<0.05$, ns $=$ not significant.

Figure 3: Receiver operating characteristic curve analysis.

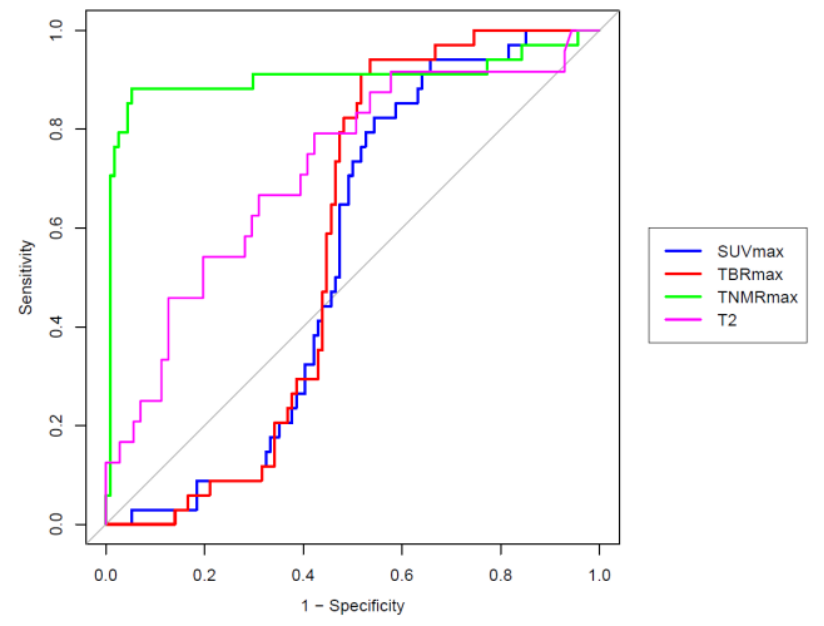

Receiver operating characteristic curve analysis for separating aCS(+) [MR(+)PET(+) FOCAL from aCS(-) [all other image-based categories]. 


\section{Discussion}

This study, with a substantially larger cohort than previous studies of MR/PET and CS, has further validated the use of MR/PET in the evaluation of CS, and specifically of TNMRmax(9) as an effective discriminator of positive active CS (Figure 2). Importantly, we also show a significant association between positive active CS and outcomes, with patients categorized as aCS(+) on MR/PET demonstrating more than 4-fold higher odds for progressing to a cardiac-related event and/or implant of a cardiac device (Table 6). The significant associations found in this study suggest that MR/PET may be able to predict future clinical events and provide useful prognostic information. Understanding disease course and prognosis with MR/PET represents a significant step and suggests that this imaging technique might be useful in guiding the initiation and monitoring of suitable anti-inflammatory or immune suppressant therapies that have shown potential benefit in $\mathrm{CS} .(17,18)$ In addition, the association of the imaging definition of $\mathrm{aCS}(+)$ and clinical events validates our strict diagnostic approach to the detection of active CS - which requires both positive PET and MR findings, and excludes more diffuse patterns of FDG-PET; it also suggests that MR/PET alone might be a useful alternative to invasive endomyocardial biopsy. The higher use of beta blockers, prevalence of syncope and the trend for increased prevalence of atrioventricular block in aCS(+) patients (Table 1) further corroborates our finding that classification of aCS(+) by imaging is consistent with disease.

In this study we expanded the image-based categories from 4 to 6 by subdividing the PET(+) categories based on the qualitative appearance and pattern of tracer uptake (Figure 1). PET $(+)_{\text {FocAL }}$ described ${ }^{18} \mathrm{~F}-$ FDG uptake in a patchy/focal distribution consistent with the guideline's description of CS, and PET $(+)_{\text {DIFFUSE }}$ described diffuse ${ }^{18}$ F-FDG uptake consistent with physiological uptake due to failed myocardial suppression. These additional categories may increase the specificity for the imaging designation of positive active CS by eliminating false positive failed myocardial suppression with quiescent disease $\left[\mathrm{MR}(+) \mathrm{PET}(+)_{\text {DIFFUSE }}\right]$ from the aCS $(+)$ group. Without categorization by pattern of ${ }^{18} \mathrm{~F}-$ FDG uptake, these cases (especially for patients with extra-cardiac disease and strong suspicion of CS) would otherwise be categorized as $\mathrm{MR}(+) \mathrm{PET}(+)$, and consequently aCS(+). This sub-categorization is supported by our finding that $\mathrm{MR}(+) \mathrm{PET}(+)_{\text {FOCAL }}$ vs. all others showed the highest odds ratio associating the imaging categorization with a cardiac-related clinical outcome, higher than MR(+)PET(+) alone $\left[\mathrm{MR}(+) \mathrm{PET}(+)_{\text {FOCAL }}\right.$ and MR(+)PET(+) DIFFUSE Vs. all others] (Table 6). Nevertheless, for subjects classified as $\operatorname{MR}(+) \operatorname{PET}(+)_{\text {DIFFUSE, }}$ herein designated as aCS(-), it is important to emphasize that active CS could not be completely ruled out since subtle, "true" focal or focal-on-diffuse CS activity might have been masked by background physiologic ${ }^{18} \mathrm{~F}$-FDG uptake. Furthermore, it is conceivable that the additional imaging category, MR(-)PET(+) FOCAL, which we classified as aCS(-), might possibly have greater sensitivity for early inflammatory changes and allow identification of pathological uptake prior to the development of myocardial injury as has been suggested by other investigators(19). Due to the small group sizes, the lack of histological verification or longer follow-up to evaluate for progression from MR(-)PET(+) $)_{\text {FOCAL }}$ to $\mathrm{MR}(+) \mathrm{PET}(+)_{\text {FOCAL, }}$ the pathophysiological correlates of this particular imaging category were not investigated. Further research will be required to better categorize the MR(+)PET $(+)_{\text {DIFFUSE }}$ and $\operatorname{MR}(-) \mathrm{PET}(+)_{\mathrm{FOCAL}}$ subgroups and to determine when and if serial, interval imaging or close monitoring for disease progression, especially for cases with a high clinical suspicion of active disease, is warranted. Taken together, these finding suggest that the combined interpretation of PET and MR data coupled 
medRxiv preprint doi: https://doi.org/10.1101/2022.01.13.22269230; this version posted January 14, 2022. The copyright holder for this preprint (which was not certified by peer review) is the author/funder, who has granted medRxiv a license to display the preprint in perpetuity.

All rights reserved. No reuse allowed without permission.

Table 3: Receiver operating characteristic curve analysis for separating aCS(+) $\left[\mathrm{MR}(+) \mathrm{PET}(+)_{\mathrm{FOCAL}}\right]$ from aCS(-) [all others].

\begin{tabular}{|c|c|c|c|c|c|}
\hline & Threshold & Sensitivity & Specificity & AUC & $\begin{array}{c}\text { AUC } 95 \% \text { confidence } \\
\text { intervals }\end{array}$ \\
\hline SUVmax & 1.5 & $94 \%$ & $34 \%$ & 0.54 & $0.43-0.65$ \\
\hline TBRmax & 1.2 & $94 \%$ & $46 \%$ & 0.57 & $0.47-0.68$ \\
\hline TNMRmax & 1.4 & $88 \%$ & $95 \%$ & 0.90 & $0.86-0.96$ \\
\hline $\mathrm{T} 2$ [ms] & 37 & $79 \%$ & $58 \%$ & 0.72 & $0.61-0.82$ \\
\hline
\end{tabular}

$A U C=$ Area under the curve, threshold $=$ the Youden index point, SUVmax = maximum standard uptake value, TBRmax = maximum target to background ratio, TNMRmax = maximum target to normal myocardium ratio, and $T 2$ $=M R$ parameter $T 2$.

Table 4: Patients meeting the composite clinical endpoint.

\begin{tabular}{|c|c|c|c|c|c|c|c|}
\hline Endpoint & $\begin{array}{c}\text { MR(+) } \\
\text { PET(+) })_{\text {FOCAL }}\end{array}$ & $\begin{array}{c}\text { MR(+) } \\
\text { PET(+) DIFFUSE }\end{array}$ & $\begin{array}{l}\text { MR(+) } \\
\text { PET(-) }\end{array}$ & $\begin{array}{c}\text { MR(-) } \\
\operatorname{PET}(+)_{\text {FOCAL }}\end{array}$ & $\begin{array}{c}\text { MR(-) } \\
\text { PET(+) DIFFUSE }\end{array}$ & $\begin{array}{l}\text { MR(-) } \\
\text { PET(-) }\end{array}$ & Total \\
\hline $\begin{array}{l}\text { ICD and VT and } \\
\text { aborted cardiac } \\
\text { arrest }\end{array}$ & $1(3 \%)$ & - & - & - & - & - & $1(3 \%)$ \\
\hline ICD and VT & $1(3 \%)$ & - & $1(3 \%)$ & - & - & - & $2(6 \%)$ \\
\hline ICD and CHB & $1(3 \%)$ & - & - & - & - & - & $1(3 \%)$ \\
\hline ICD & $3(10 \%)$ & - & - & $1(3 \%)$ & $2(6 \%)$ & $1(3 \%)$ & $7(23 \%)$ \\
\hline S-ICD & - & - & - & - & $1(3 \%)$ & $1(3 \%)$ & $2(6 \%)$ \\
\hline WCD & - & - & - & - & $1(3 \%)$ & - & $1(3 \%)$ \\
\hline CRT-D & $3(10 \%)$ & - & - & - & - & - & $3(10 \%)$ \\
\hline ILR & $6(19 \%)$ & $1(3 \%)$ & $4(13 \%)$ & - & - & $3(10 \%)$ & $14(45 \%)$ \\
\hline Total & $15(48 \%)$ & $1(3 \%)$ & $5(16 \%)$ & $1(3 \%)$ & $4(13 \%)$ & $5(16 \%)$ & $31(100 \%)$ \\
\hline
\end{tabular}

Number of patients and percent of all patients meeting the clinical endpoint (in parentheses) are given in the table. $I C D=$ implantable cardioverter defibrillator; $V T=$ ventricular tachycardia; $C H B=$ complete heart block; $S$-ICD = subcutaneous implantable cardioverter defibrillator; $W C D=$ wearable cardioverter defibrillator; $C R T-D=$ cardiac resynchronization therapy device; ILR = implantable loop recorder. 
with the patchy/focal pattern of the ${ }^{18} \mathrm{~F}-\mathrm{FDG}$ uptake, is a better indicator of association with a cardiacrelated clinical outcome and, therefore, disease severity.

In addition to the qualitative metrics described above, quantitative values of SUVmax and TBRmax in the aCS $(+)$ group $\left[\mathrm{MR}(+) \mathrm{PET}(+)_{\text {FOCAL }}\right]$ were significantly lower than other PET(+) categories $\left[\mathrm{MR}(+) \mathrm{PET}(+)_{\text {DIFFuSE, }}\right.$ $\left.\operatorname{MR}(-) \operatorname{PET}(+)_{\text {FOCAL, }} \mathrm{MR}(-) \mathrm{PET}(+)_{\text {DIFFUSE }}\right]$. These data indicate that quantitative analysis of SUVmax and TBRmax may allow discrimination between uptake associated with inflammation vs. physiological or non-specific uptake.

Together with the pattern of ${ }^{18} \mathrm{~F}-\mathrm{FDG}$ uptake, analysis of $\mathrm{T} 2$ values (Figure 2) may prove useful in separating pathological from physiological uptake. When all $\mathrm{MR}(+)$ cases were combined and compared to all $M R(-)$ cases combined, $T 2$ for the $M R(+)$ group $(41.0 \pm 9.1 \mathrm{~ms})$ was significantly higher than for the $\mathrm{MR}(-)$ group $(36.1 \pm 4.6 \mathrm{~ms}), \mathrm{p}=0.001$, correlating with the presence of LGE. Notably, within the MR(+) groups, there was a trend $(p=0.07)$ for $\mathrm{MR}(+) \mathrm{PET}(+)_{\mathrm{FOCAL}}$ to show higher T2 values $(43.3 \pm 11.0 \mathrm{~ms})$ compared to MR(+)PET(+) DIFFUSE and MR(+)PET(-) groups combined (38.6 $\pm 5.9 \mathrm{~ms}$ ). These data indicate an association between T2 and focal ${ }^{18}$ F-FDG uptake characteristic of inflammation that occurs in the presence of LGE. For the MR(-) groups, there was no comparable significant difference $(p=0.96)$

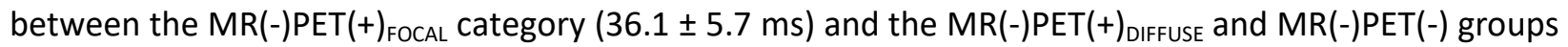
combined (36.0 $\pm 4.2 \mathrm{~ms})$.

The expansion of the imaging categories coupled with the T2 analysis suggest the potential utility of more sophisticated multi-parametric models to characterize active CS disease and separate pathological, physiological and mixed ${ }^{18} \mathrm{~F}$-FDG uptake. A future model would include analysis of TNMRmax to characterize patchy/focal ${ }^{18}$ F-FDG uptake, SUVmax to characterize physiological ${ }^{18} \mathrm{~F}$-FDG uptake, as well as the MR parameters: LGE, to define myocardial injury, and T2, to confirm myocardial inflammation. In addition, secondary parameters such as spatial heterogeneity of ${ }^{18} \mathrm{~F}$-FDG uptake(20) and kinetic analysis of ${ }^{18} \mathrm{~F}$-FDG uptake $(9,21)$ could be useful. Such models would require histological validation.

\section{Limitations}

The evaluation of prognosis is limited by the relatively small patient cohort and the limited number who progressed to the clinical endpoint within the follow-up period. Furthermore, a relatively short duration of follow-up in this cohort study has limited the extent of clinical progression that would be necessary to provide a more detailed evaluation of the prognostic ability of the imaging results. Further studies with larger cohorts, longer follow-up and time-to-event models are required to evaluate clinical manifestations specific to prognosis of CS, beyond the cardiac-related clinical outcomes used in this study. Device implantation, which was ubiquitous in those who met the clinical endpoint, is related to arrhythmia and therefore was, a priori, expected to correlate with scarring seen on LGE MR. $(22,23)$ The follow-up period was not sufficient to evaluate the impact of early stages of inflammation that could be reflected by MR(-)PET(+) findings, to manifest in scarring, arrhythmias and device implantation, therefore the impact of the PET(+) imaging designation is likely underestimated, consistent with the fact that $\mathrm{MR}(+)$ alone $\left[\mathrm{MR}(+) \mathrm{PET}(+)_{\text {FOCAL, }} \mathrm{MR}(+) \operatorname{PET}(+)_{\text {DIFFUSE }}\right.$ and MR(+)PET(-) vs. all others] showed a higher odds of progressing to the clinical outcome than PET(+) alone $\left[\mathrm{MR}(+) \operatorname{PET}(+)_{\text {FOCAL, }} \mathrm{MR}(+) \mathrm{PET}(+)_{\text {DIFFUSE, }}\right.$ MR(-)PET(+) FOCAL, and MR(-)PET(+) DIFFUSE vs. all others]. An additional limitation is the lack of a gold standard confirmation that inflammation is the underlying mechanism of myocardial ${ }^{18} \mathrm{~F}$-FDG uptake. 
medRxiv preprint doi: https://doi.org/10.1101/2022.01.13.22269230; this version posted January 14, 2022. The copyright holder for this preprint (which was not certified by peer review) is the author/funder, who has granted medRxiv a license to display the preprint in perpetuity.

All rights reserved. No reuse allowed without permission.

${ }^{18}$ F-FDG has been correlated with inflammation in other applications(24) yet we cannot rule-out increased metabolic activity of the cardiomyocytes as the underlying mechanism for the increased myocardial ${ }^{18} \mathrm{~F}$-FDG uptake observed in the setting of CS. Use of novel tracers to assess myocardial inflammation without background myocardial signal such as ${ }^{68} \mathrm{Ga}$-DOTATATE(25) or ${ }^{68} \mathrm{Ga-DOTANOC}(26)$ may be useful to confirm the findings.

\section{Conclusions}

Hybrid MR/PET imaging with an extended image-based classification for diagnosis of CS is associated with cardiac-related clinical outcomes in CS. Moreover, target-to-normal-myocardium ratio (TNMRmax) has high sensitivity and excellent specificity for quantifying the imaging-based classification of active CS. Further studies are required to validate the imaging-based strategy for diagnosis and prognosis.

Table 5: Cardiac-related clinical outcome events by analysis groups for each group.

\begin{tabular}{ccccc}
\hline Analysis & & Event & Non-event & $\begin{array}{c}\text { Events-to-non- } \\
\text { events ratio (\%) }\end{array}$ \\
\hline \multirow{2}{*}{$\mathbf{1}$} & $\mathrm{aCS}(+)$ & $15(10)$ & $19(13)$ & 79 \\
& $\mathrm{aCS}(-)$ & $16(11)$ & $98(66)$ & 16 \\
\hline $\mathbf{2}$ & $\mathrm{MR}(+) \mathrm{PET}(+)$ & $16(11)$ & $32(22)$ & 50 \\
& Non MR(+)PET(+) & $15(10)$ & $85(57)$ & 18 \\
\hline \multirow{2}{*}{$\mathbf{3}$} & $\mathrm{PET}(+)$ & $21(14)$ & $66(45)$ & 32 \\
& $\mathrm{PET}(-)$ & $10(7)$ & $51(34)$ & 20 \\
\hline & $\mathrm{MR}(+)$ & $21(14)$ & $50(34)$ & 42 \\
& $\mathrm{MR}(-)$ & $67(45)$ & 15 \\
\hline
\end{tabular}

Events and non-events are given as number (n) and percent of all patients (\%) in parentheses. Analysis 1: aCS(+) $\left[M R(+) P E T(+)_{\text {FOCAL }}\right.$ vs. aCS(-) [all others]; analysis 2: MR(+)PET(+) [MR(+)PET $(+)_{\text {FOCAL }}$ and MR $\left.(+) P E T(+)_{D I F F U S E}\right]$ vs. Non $M R(+) P E T(+)$ [all others]; analysis 3: PET $(+)\left[M R(+) P E T(+)_{\text {FOCAL }} M R(-) P E T(+)_{\text {FOCAL }} M R(+) P E T(+)_{\text {DIFFUSE, }}\right.$ and MR(JPET $(+)_{\text {DIFFUSE] }}$ vs. PET(-) [all others]; analysis 4: MR(+) [MR(+)PET(+) FOCAL MR(+)PET(+) DIFFUSE, MR(+)PET(-)] vs. MR(-) [all others]. 
medRxiv preprint doi: https://doi.org/10.1101/2022.01.13.22269230; this version posted January 14, 2022. The copyright holder for this preprint (which was not certified by peer review) is the author/funder, who has granted medRxiv a license to display the preprint in perpetuity.

All rights reserved. No reuse allowed without permission.

Table 6: Association of analysis groups with cardiac-related clinical outcomes.

\begin{tabular}{ccccc}
\hline Analysis & $\begin{array}{c}\text { Odds of having a cardiac-related } \\
\text { clinical outcome/event }\end{array}$ & OR & Cl & P \\
\hline $\mathbf{1}$ & aCS(+) vs. aCS(-) & 4.8 & $2.0-11.4$ & 0.00032 \\
$\mathbf{2}$ & $\begin{array}{l}\mathrm{MR}(+) \mathrm{PET}(+) \text { vs. } \\
\text { non MR(+)PET(+) }\end{array}$ & 2.8 & $1.3-6.4$ & 0.012 \\
$\mathbf{3}$ & $\mathrm{PET}(+)$ vs. PET(-) & 1.6 & $0.7-3.7$ & 0.26 \\
& $\mathrm{MR}(+)$ vs. MR(-) & 2.8 & $1.2-6.5$ & 0.015 \\
\hline
\end{tabular}

Analysis 1: aCS(+) [MR(+)PET(+) FOCAL] vs. aCS(-) [all others]; analysis 2: $M R(+) P E T(+)\left[M R(+) P E T(+)_{\text {FOCAL }}\right.$ and $\left.M R(+) P E T(+)_{D I F F U S E}\right]$ vs. Non MR(+)PET( + ) [all others]; analysis 3: PET $(+)\left[M R(+) P E T(+)_{\text {FOCAL }} M R(-) P E T(+)_{\text {FOCAL }}\right.$ $M R(+) P E T(+)_{\text {DIFEUSE, }}$ and MR(-)PET(+) DIFFUSE] vs. PET(-) [all others]; analysis 4: $M R(+)\left[M R(+) P E T(+)_{\text {FOCAL }}\right.$ $\left.M R(+) P E T(+)_{\text {DIFEUSE, }} M R(+) P E T(-)\right]$ vs. $M R(-)$ [all others]. OR = odds ratio; $C l=95 \%$ confidence interval; $p$-values are for a two-sided test of significance for the odds ratio.

\section{References}

1. Morimoto T., Azuma A., Abe S., et al. Epidemiology of sarcoidosis in Japan. Eur Respir J 2008;31(2):372-9. Doi: 10.1183/09031936.00075307.

2. Iannuzzi MC., Rybicki BA., Teirstein AS. Sarcoidosis. New England Journal of Medicine 2007;357(21):2153-65. Doi: 10.1056/NEJMra071714.

3. Birnie DH., Nery PB., Ha AC., Beanlands RSB. Cardiac Sarcoidosis. J Am Coll Cardiol 2016;68(4):41121. Doi: $10.1016 / j$.jacc.2016.03.605.

4. Silverman KJ., Hutchins GM., Bulkley BH. Cardiac sarcoid: a clinicopathologic study of 84 unselected patients with systemic sarcoidosis. Circulation 1978;58(6):1204-11.

5. Perry A., Vuitch F. Causes of death in patients with sarcoidosis. A morphologic study of 38 autopsies with clinicopathologic correlations. Arch Pathol Lab Med 1995;119(2):167-72.

6. Birnie DH., Sauer WH., Bogun F., et al. HRS expert consensus statement on the diagnosis and management of arrhythmias associated with cardiac sarcoidosis. Heart Rhythm 2014;11(7):130523. Doi: 10.1016/j.hrthm.2014.03.043.

7. Greulich S., Deluigi CC., Gloekler S., et al. CMR imaging predicts death and other adverse events in suspected cardiac sarcoidosis. JACC Cardiovasc Imaging 2013;6(4):501-11. Doi: 10.1016/j.jcmg.2012.10.021.

8. Blankstein R., Osborne M., Naya M., et al. Cardiac positron emission tomography enhances prognostic assessments of patients with suspected cardiac sarcoidosis. J Am Coll Cardiol 2014;63(4):329-36. Doi: 10.1016/j.jacc.2013.09.022. 
medRxiv preprint doi: https://doi.org/10.1101/2022.01.13.22269230; this version posted January 14, 2022. The copyright holder for this preprint (which was not certified by peer review) is the author/funder, who has granted medRxiv a license to display the preprint in perpetuity.

All rights reserved. No reuse allowed without permission.

9. Dweck MR., Abgral R., Trivieri MG., et al. Hybrid Magnetic Resonance Imaging and Positron Emission Tomography With Fluorodeoxyglucose to Diagnose Active Cardiac Sarcoidosis. JACC Cardiovasc Imaging 2017. Doi: 10.1016/j.jcmg.2017.02.021.

10. Wicks EC., Menezes L., Barnes A., et al. Diagnostic accuracy and prognostic value of simultaneous hybrid 18F-fluorodeoxyglucose positron emission tomography/magnetic resonance imaging in cardiac sarcoidosis. Eur Heart J Cardiovasc Imaging 2018;19(7):757-67. Doi: 10.1093/ehjci/jex340.

11. Vergani V., Busnardo E., Mapelli P., et al. Hybrid cardiac PET/MR: the value of multiparametric assessment in cardiac sarcoidosis. Clin Transl Imaging 2019;7(5):317-26. Doi: 10.1007/s40336-01900345-0.

12. Chareonthaitawee P., Beanlands RS., Chen W., et al. Joint SNMMI-ASNC expert consensus document on the role of 18F-FDG PET/CT in cardiac sarcoid detection and therapy monitoring. J Nucl Cardiol 2017;24(5):1741-58. Doi: 10.1007/s12350-017-0978-9.

13. Robson PM., Dweck MR., Trivieri MG., et al. Coronary Artery PET/MR Imaging: Feasibility, Limitations, and Solutions. JACC Cardiovasc Imaging 2017;10(10 Pt A):1103-12. Doi: 10.1016/j.jcmg.2016.09.029.

14. Schulz-Menger J., Bluemke DA., Bremerich J., et al. Standardized image interpretation and post processing in cardiovascular magnetic resonance: Society for Cardiovascular Magnetic Resonance (SCMR) board of trustees task force on standardized post processing. J Cardiovasc Magn Reson 2013;15:35. Doi: 10.1186/1532-429X-15-35.

15. Cerqueira MD., Weissman NJ., Dilsizian V., et al. Standardized myocardial segmentation and nomenclature for tomographic imaging of the heart. A statement for healthcare professionals from the Cardiac Imaging Committee of the Council on Clinical Cardiology of the American Heart Association. Circulation 2002;105(4):539-42. Doi: 10.1161/hc0402.102975.

16. Ferreira VM., Schulz-Menger J., Holmvang G., et al. Cardiovascular Magnetic Resonance in Nonischemic Myocardial Inflammation: Expert Recommendations. J Am Coll Cardiol 2018;72(24):3158-76. Doi: 10.1016/j.jacc.2018.09.072.

17. Nagai T., Nagano N., Sugano Y., et al. Effect of Corticosteroid Therapy on Long-Term Clinical Outcome and Left Ventricular Function in Patients With Cardiac Sarcoidosis. Circ J 2015;79(7):1593600. Doi: 10.1253/circj.CJ-14-1275.

18. Ballul T., Borie R., Crestani B., et al. Treatment of cardiac sarcoidosis: A comparative study of steroids and steroids plus immunosuppressive drugs. Int J Cardiol 2019;276:208-11. Doi: 10.1016/j.ijcard.2018.11.131.

19. Ohira H., Birnie DH., Pena E., et al. Comparison of (18)F-fluorodeoxyglucose positron emission tomography (FDG PET) and cardiac magnetic resonance (CMR) in corticosteroid-naive patients with conduction system disease due to cardiac sarcoidosis. Eur J Nucl Med Mol Imaging 2016;43(2):25969. Doi: $10.1007 / \mathrm{s} 00259-015-3181-8$.

20. Tahara N., Tahara A., Nitta Y., et al. Heterogeneous myocardial FDG uptake and the disease activity in cardiac sarcoidosis. JACC Cardiovasc Imaging 2010;3(12):1219-28. Doi: 10.1016/j.jcmg.2010.09.015.

21. Karakatsanis N., Trivieri M., Abgral R., et al. Direct 4D Patlak 18F-FDG PET/MR for the MultiParametric Assessment of active cardiac sarcoidosis. 2017.

22. Gulati A., Jabbour A., Ismail TF., et al. Association of fibrosis with mortality and sudden cardiac death in patients with nonischemic dilated cardiomyopathy. JAMA 2013;309(9):896-908. Doi: 10.1001/jama.2013.1363.

23. Disertori M., Rigoni M., Pace N., et al. Myocardial Fibrosis Assessment by LGE Is a Powerful Predictor of Ventricular Tachyarrhythmias in Ischemic and Nonischemic LV Dysfunction: A Meta-Analysis. JACC Cardiovasc Imaging 2016;9(9):1046-55. Doi: 10.1016/j.jcmg.2016.01.033. 
medRxiv preprint doi: https://doi.org/10.1101/2022.01.13.22269230; this version posted January 14, 2022. The copyright holder for this preprint

(which was not certified by peer review) is the author/funder, who has granted medRxiv a license to display the preprint in perpetuity.

All rights reserved. No reuse allowed without permission.

24. Vaidyanathan S., Patel CN., Scarsbrook AF., Chowdhury FU. FDG PET/CT in infection and inflammation--current and emerging clinical applications. Clin Radiol 2015;70(7):787-800. Doi: 10.1016/j.crad.2015.03.010.

25. Bravo PE., Bajaj N., Padera RF., et al. Feasibility of somatostatin receptor-targeted imaging for detection of myocardial inflammation: A pilot study. J Nucl Cardiol 2021;28(3):1089-99.

26. Gormsen LC., Haraldsen A., Kramer S., Dias AH., Kim WY., Borghammer P. A dual tracer (68)GaDOTANOC PET/CT and (18)F-FDG PET/CT pilot study for detection of cardiac sarcoidosis. EJNMMI Res 2016;6(1):52. Doi: 10.1186/s13550-016-0207-6. 